\title{
Significant Independent Predictors of Vitamin D Deficiency in Inpatients and Outpatients of a Nephrology Unit
}

\author{
Recep Bentli, ${ }^{1}$ Hulya Taskapan, ${ }^{2}$ Halil Toktaş, ${ }^{1}$ Ozkan Ulutas, ${ }^{2}$ \\ Adnan Ozkahraman, ${ }^{1}$ and Melda Comert ${ }^{1}$ \\ ${ }^{1}$ Internal Medicine Department, Medical Faculty, Inonu University, Malatya, Turkey \\ ${ }^{2}$ Nephrology Department, Medical Faculty, Inonu University, Malatya, Turkey \\ Correspondence should be addressed to Recep Bentli; dr_bentli@hotmail.com
}

Received 26 February 2013; Revised 1 April 2013; Accepted 15 April 2013

Academic Editor: Ibrahim Sahin

Copyright (C) 2013 Recep Bentli et al. This is an open access article distributed under the Creative Commons Attribution License, which permits unrestricted use, distribution, and reproduction in any medium, provided the original work is properly cited.

\begin{abstract}
Aims. Kidney disease was found to be a major risk factor for vitamin D deficiency in a population study of patients hospitalized. The aims of the study were to describe the prevalence of vitamin D deficiency inpatients and outpatients in a nephrology department during fall and to evaluate effect of assessing serum 25-hydroxyvitamin D (25(OH)D) levels and previous supplementation of cholecalciferol on vitamin D status. Methods. We studied 280 subjects in total, between October and January. The subjects were recruited from the following two groups: (a) inpatients and (b) outpatients in nephrology unit. We examined previous documentary evidence of vitamin D supplementation of the patients. Results. The prevalence of vitamin D deficiency among these 280 patients was $62,1 \%$ (174 patients). Fifty-three patients (18.9\%) had severe vitamin D deficiency, 121 patients (43.2\%) moderate vitamin D deficiency, and 66 patients (23.6\%) vitamin D insufficiency. In logistic regression analysis female gender, not having vitamin D supplementation history, low serum albumin, and low blood urea nitrogen levels were significant independent predictors of vitamin $\mathrm{D}$ deficiency while no association of vitamin D deficiency with diabetes mellitus, serum creatinine, eGFR, and being hospitalized was found. Conclusion. Vitamin D deficiency, seems to be an important problem in both inpatients and outpatients of nephrology. Monitoring serum 25(OH)D concentrations regularly and replacement of vitamin D are important. Women in Turkey are at more risk of deficiency and may therefore need to consume higher doses of vitamin D.
\end{abstract}

\section{Introduction}

Vitamin D deficiency is reemerging as a major public health problem throughout the world. It is acknowledged that the prevalence of vitamin D deficiency and its associated morbidities are higher than previously thought worldwide. In addition to metabolic bone disease, recent studies reported that vitamin D deficiency could increase the risk of certain cancers, heart disease, and autoimmune diseases including rheumatoid arthritis and multiple sclerosis in adults and diabetes mellitus [1-8].

Chronic vitamin D deficiency may have serious adverse consequences in patients with kidney disease [9-13]. To test the hypothesis that low serum 25-hydroxyvitamin D $(25(\mathrm{OH}) \mathrm{D})$ levels are a risk factor for kidney disease progression, Melamed et al. analyzed data from 13,328 participants in the National Health and Nutrition Examination Survey (NHANES) III Follow-Up Study, in which 25(OH)D levels were measured from 1988 through 1994, and then participants were followed for up to 12 years. The incidence of end-stage renal disease was 2.6 times greater in people whose serum $25(\mathrm{OH}) \mathrm{D}$ was less than $15 \mathrm{ng} / \mathrm{mL}$ than in those with higher levels [14].

However, it is still not common practice among nephrologists to monitor and correct vitamin D deficiency of patients with kidney disease, because it is widely believed that the capacity of the $1 \alpha$-hydroxylase to synthesize $1,25(\mathrm{OH})_{2} \mathrm{D}_{3}$ decreases progressively because of decreased renal mass and that any vitamin D deficiency associated with calciumphosphate disturbances is better treated with activated vitamin D. 
Although hypovitaminosis D has been reported frequently in patients with kidney disease, the prevalence of vitamin D deficiency among patients hospitalized in nephrology services is unknown.

The aims of the study were to describe and compare the prevalence of vitamin D deficiency inpatients and outpatients in the nephrology department during early winter and to evaluate effect of assessing serum 25(OH)D levels and previous supplementation of cholecalciferol on vitamin D status.

\section{Material Methods}

We undertook a retrospective audit of the serum $25(\mathrm{OH}) \mathrm{D}$ levels of inpatients and outpatients in the nephrology departments from October 15, 2010 to January 1, 2011, and previous serum $25(\mathrm{OH}) \mathrm{D}$ analysis, and previous vitamin $\mathrm{D}$ supplementation history of the patients. The study was approved by the Ethics Committee.

The following information was determined from the patients' medical records: age, gender, primary underlying renal diagnosis, blood urea nitrogen (BUN), serum creatinine, corrected total serum calcium, serum phosphorus, intact parathormone (iPTH), serum albumin levels, recent and preceding results of serum $25(\mathrm{OH}) \mathrm{D}$ analysis, and previous documentary evidence of vitamin $\mathrm{D}$ supplementation. Estimated GFR (eGFR), using the abbreviated Modification in Diet in Renal Disease (MDRD) equation, was determined [15].

Vitamin D deficiency was defined as $25(\mathrm{OH}) \mathrm{D}$ levels below $15 \mathrm{ng} / \mathrm{mL}(37.4 \mathrm{nM} / \mathrm{L})$. For subanalysis the patients were divided into four diagnostic categories according to their serum $25(\mathrm{OH}) \mathrm{D}$ levels: severe vitamin $\mathrm{D}$ deficiency (serum $25(\mathrm{OH}) \mathrm{D}_{3}$ level, less than $5 \mathrm{ng} / \mathrm{mL},(12,5 \mathrm{nM} / \mathrm{L})$ ), moderate vitamin $\mathrm{D}$ deficiency (serum $25(\mathrm{OH}) \mathrm{D}_{3}$ level, 5 to $15 \mathrm{ng} / \mathrm{mL}(12.5-37.4 \mathrm{nM} / \mathrm{L})$ ), vitamin $\mathrm{D}$ insufficiency (serum $25(\mathrm{OH}) \mathrm{D}_{3}$ level, 15 to $30 \mathrm{ng} / \mathrm{mL}(12.5-37.4 \mathrm{nM} / \mathrm{L})$ ), and adequate vitamin $\mathrm{D}$ stores (serum $25(\mathrm{OH}) \mathrm{D}_{3}$ level, more than $30 \mathrm{ng} / \mathrm{mL}(37.4 \mathrm{nM} / \mathrm{L}))[16]$.

\section{Statistical Analyses}

Data are expressed as mean \pm SD. The significance of difference between continuous variables was tested using unpaired $t$-test or Mann-Whitney rank sum test and for categorical variables using -2 or Fisher exact test as appropriate. Correlations were tested using Spearman correlation coefficient. $P$ values less than 0.05 were regarded as statistically significant. Logistic regression analysis, binary logistic (HosmerLemshow goodness of fit) by enter method, was studied.

\section{Results}

In the local biochemistry database we identified $25(\mathrm{OH}) \mathrm{D}$ requests in total 280 inpatients and outpatients in the Nephrology Department between October 15, 2010 and January 1, 2011.

Diagnosis of the patients were given in Table 1. A total of $49(17.5 \%)$ patients were receiving dialysis $(17(34,7 \%)$ due to
TABLE 1: Diagnosis of the patients.

\begin{tabular}{lc}
\hline Diagnosis & Frequency (\%) \\
\hline Acute renal failure & $13(4.6)$ \\
Chronic kidney disease & $230(82.1)$ \\
Acute renal failure on chronic kidney disease & $4(1.4)$ \\
Hypernatremia & $1(0.4)$ \\
Hyponatremia & $1(0.4)$ \\
Glomerulonephritis & $8(2.9)$ \\
Renal transplantation & $9(3.2)$ \\
Urinary infection & $2(0.7)$ \\
Hypertension & $12(4.3)$ \\
\hline Total & $280(100.0)$ \\
\hline
\end{tabular}

acute renal failure, and all these were inpatients. Sixty-three patients $(22.5 \%)$ were diabetic. Demographic and clinical characteristics of inpatients and outpatients are shown at Table 2.

The prevalence of vitamin D deficiency among these 280 patients was $62,1 \%$ (174 patients). Fifty-three patients (18.9\%) had severe vitamin D deficiency, 121 patients (43.2\%) moderate vitamin $\mathrm{D}$ deficiency, and 66 patients $(23.6 \%)$ vitamin $\mathrm{D}$ insufficiency. Only 40 (14.3\%) patients had adequate vitamin $\mathrm{D}$ stores. Whereas in patients with vitamin D deficiency, age, BUN, and $\mathrm{PTH}$ were higher, serum albumin, calcium levels were lower. There was no significant difference according to serum phosphorus, creatinine, and eGFR $(P>0,05)$ (Table 3).

While in $72 \%$ of the inpatients ( $n$ : 90$)$ serum $25(\mathrm{OH}) \mathrm{D}$ levels were less than $15 \mathrm{ng} / \mathrm{mL}(37.4 \mathrm{nM} / \mathrm{L})$, in $54.2 \%$ of the outpatients ( $n$ : 86$)$ serum $25(\mathrm{OH}) \mathrm{D}$ levels were less than $15 \mathrm{ng} / \mathrm{mL}(37.4 \mathrm{nM} / \mathrm{L})(P<0.05)$. While age, BUN, serum creatinine, and phosphorus levels of inpatients were higher, serum $25(\mathrm{OH}) \mathrm{D}$, serum calcium, albumin levels, and eGFR of inpatients were lower than those of outpatients $(P<0,05)$. No significant difference was found according to serum iPTH levels between inpatients and outpatients.

Of 280 patients, $156(55.7 \%)$ had at least one measurement of $25(\mathrm{OH}) \mathrm{D}$ levels during the previous followup in our nephrology unit. Of these 280 patients, 55.7\% (156) were previously supplemented with cholecalciferol according to vitamin D supplementation protocol of our nephrology unit. The mean duration between recent and preceding measurements of serum $25(\mathrm{OH}) \mathrm{D}$ levels and initiation of vitamin $\mathrm{D}$ supplementation was $9.9 \pm 3.9$ months. The preceding mean serum 25(OH)D level was $12.4 \pm 6.8 \mathrm{ng} / \mathrm{mL}(30.9 \pm$ $16.7 \mathrm{nM} / \mathrm{L})$.

Of 174 patients with vitamin D deficiency, 83 (47.7\%) and $73(68.9 \%)$ of 106 patients without vitamin D deficiency had vitamin D supplementation history. Of 125 inpatients, 57 (45.6\%) and 99 (63.9\%) of 155 outpatients had vitamin D supplementation history $(P<0,05)$. No difference was found between patients supplemented with vitamin $\mathrm{D}$ previously or not according to BUN, serum albumin, and phosphorus. While inpatients supplemented with vitamin D previously, age $(50,8 \pm 16,6$ versus $58,1 \pm 16,7$ years $)$, hospitalization days 
TABLE 2: Demographic and laboratory results of the inpatients and outpatients.

\begin{tabular}{|c|c|c|c|c|}
\hline Variable & All patients $(n=280)$ & Inpatients $(n=125)$ & Outpatients $(n=155)$ & $P$ value \\
\hline Age (years) & $54.06 \pm 16.9(18-91)$ & $56.9 \pm 18(18-91)$ & $51.8 \pm 15.4(21-84)$ & 0.008 \\
\hline Hospitalization days & - & $13.8 \pm 11.2(1-60)$ & - & - \\
\hline $\begin{array}{l}\text { Serum } 25(\mathrm{OH}) \mathrm{D} \text { levels }(\mathrm{ng} / \mathrm{mL}) \\
(\mathrm{nM} / \mathrm{L})\end{array}$ & $\begin{array}{l}16.5 \pm 15.9(0.4-110) \\
\quad(41.2 \pm 39.7)\end{array}$ & $\begin{array}{l}13.5 \pm 15.9(0.4-110) \\
\quad(33.7 \pm 39.7)\end{array}$ & $\begin{array}{l}18.9 \pm 15.6(1-82.8) \\
\quad(47.2 \pm 38.9)\end{array}$ & $<0.001$ \\
\hline Blood urea nitrogen $(\mathrm{mg} / \mathrm{dL})$ & $54.4 \pm 35.54(7-185)$ & $66.3 \pm 37.3(10-185)$ & $43.1 \pm 19.8(7-102)$ & $<0.001$ \\
\hline Serum creatinine $(\mathrm{mg} / \mathrm{dL})$ & $5.8 \pm 3.7(0.6-17.8)$ & $6.3 \pm 3.8(0.7-17.8)$ & $5.4 \pm 3.8(0.6-16.8)$ & 0.021 \\
\hline Serum albumin (mg/dL) & $3.4 \pm 0.7(0.5-4.8)$ & $3.10 \pm 0.7(0.5-4.5)$ & $3.6 \pm 0.6(1.7-4.8)$ & $<0.001$ \\
\hline Serum calcium (mg/dL) & $9.0 \pm 0.9(6.0-12.7)$ & $8.6 \pm 0.9(6.0-12.0)$ & $9.2 \pm 0.8(7.3-12.7)$ & $<0.001$ \\
\hline Serum phosphorus (mg/dL) & $4.7 \pm 1.6(1.9-11.9)$ & $5.2 \pm 1.8(1.9-11.9)$ & $4.3 \pm 1.3(1.9-10.1)$ & $<0.001$ \\
\hline Serum parathyroid hormone (pg/mL) & $\begin{array}{c}376.9 \pm 425.9 \\
(10.9-2500)\end{array}$ & $377.2 \pm 362.3(35.3-2258)$ & $376.8 \pm 472.7(10.9-2500)$ & NS \\
\hline $\mathrm{eGFR}\left(\mathrm{mL} / \mathrm{min} / 1.73 \mathrm{~m}^{2}\right)$ & $24.6 \pm 31.8(1.5-125)$ & $16.4 \pm 20.8(1.5-125)$ & $31.3 \pm 37.2(2.1-125)$ & 0.001 \\
\hline $\begin{array}{l}\text { Patients previously supplemented with } \\
\text { cholecalcipherol }\end{array}$ & & $57(45.6 \%)$ & $99(63.9 \%)$ & 0.003 \\
\hline
\end{tabular}

The data were mean $\pm \mathrm{SD}(\min -\max )$ or frequency $(\%)$.

TABle 3: Demographic and laboratory results of the patients with and without vitamin D deficiency.

\begin{tabular}{|c|c|c|c|}
\hline Variable & $\begin{array}{l}\text { Patients with vitamin D deficiency } \\
\qquad(n=174)\end{array}$ & $\begin{array}{l}\text { Patients without vitamin D deficiency } \\
\qquad(n=106)\end{array}$ & $P$ \\
\hline Age (years) & $55.6 \pm 18.1(18-91)$ & $51.5 \pm 14.8(18-79)$ & 0.033 \\
\hline Hospitalization days & $7.8 \pm 11.7(0-60)$ & $3.3 \pm 5.9(0-28)$ & 0.001 \\
\hline Blood urea nitrogen (mg/dL) & $59.1 \pm 33.8(9-185)$ & $44.6 \pm 25.1(7-185)$ & $<0.001$ \\
\hline Serum creatinine $(\mathrm{mg} / \mathrm{dL})$ & $5.8 \pm 3.8(0.6-17.9)$ & $5.7 \pm 3.9(0.6-14.7)$ & NS \\
\hline Serum albumin $(\mathrm{mg} / \mathrm{dL})$ & $3.2 \pm 0.7(0.5-4.8)$ & $3.6 \pm 0.5(2.4-4.7)$ & $<0.001$ \\
\hline Serum calcium $(\mathrm{mg} / \mathrm{dL})$ & $8.9 \pm 0.9$ & $9.2 \pm 0.9(7-12.7)$ & 0.002 \\
\hline Serum phosphorus (mg/dL) & $4.8 \pm 1.7(1.9-11.9)$ & $4.5 \pm 1.4(1.9-8.8)$ & NS \\
\hline Serum parathyroid hormone (pg/mL) & $398.5 \pm 408.3(20.3-2500)$ & $342.2 \pm 452.7(10.9-2500)$ & 0.004 \\
\hline $\mathrm{eGFR}\left(\mathrm{mL} / \mathrm{min} / 1.73 \mathrm{~m}^{2}\right)$ & $23.4 \pm 32.3(1.5-125)$ & $26.7 \pm 31.0(2.1-125)$ & NS \\
\hline Previously treated with cholecalcipherol & $83(47.7 \%)$ & $73(68.9)$ & 0.001 \\
\hline
\end{tabular}

The data were mean \pm SD $(\min -\max )$ or frequency $(\%)$.

$(4,7 \pm 9,2$ versus $7,9 \pm 11,1$ days $)$, and eGFR $(15,2 \pm 21,1$ versus $\left.36,5 \pm 38,4 \mathrm{~mL} / \mathrm{min} / 1.73 \mathrm{~m}^{2}\right)$ were significantly lower, and serum $25(\mathrm{OH}) \mathrm{D}(20,2 \pm 18,3$ versus $11,9 \pm 10,8 \mathrm{ng} / \mathrm{mL}$, $50.4 \pm 45.7$ versus $29.7 \pm 26.9 \mathrm{nM} / \mathrm{L})$, creatinine $(7,1 \pm 3,7$ versus 4,3 $\pm 3,9 \mathrm{mg} / \mathrm{dL})$, calcium $(9,4 \pm 3,4$ versus $8,7 \pm 1,1 \mathrm{mg} / \mathrm{dL})$, and PTH $(443,9 \pm 468,2$ versus $289,6 \pm 346,5 \mathrm{pg} / \mathrm{mL})$ levels were significantly higher $(P<0.05)$.

Serum $25(\mathrm{OH}) \mathrm{D}$ levels were statistically lower in females than males $(15,2 \pm 16,8$ versus $18,2 \pm 14,7 \mathrm{ng} / \mathrm{mL} ; 45.4 \pm 42$ versus $37.9 \pm 41.9 \mathrm{nM} / \mathrm{L}$, resp. $)(P<0.05)$. The prevalence of vitamin D deficiency among these 153 women was $69.3 \%$ (106 patients) and $43.5 \%$ in men (68 patients) $(P<0,05)$.

Of 153 female patients with vitamin D deficiency, 91 (56.8\%) and $65(59.3 \%)$ of 127 male patients with vitamin $\mathrm{D}$ deficiency had vitamin $\mathrm{D}$ supplementation history $(P>$ $0,05)$. The mean duration between recent and preceding measurements of $25(\mathrm{OH}) \mathrm{D}$ levels and initiation of vitamin $\mathrm{D}$ supplementation was $10.3 \pm 3.6$ months in female patients and $9.7 \pm 4.1$ months in male patients $(P>0.05)$. No difference was found between males and females according to age, BUN, serum albumin, calcium, phosphorus, PTH, eGFR, and hospitalization days $(P>0,05)$. Serum creatinine was lower in female patients $(5,3 \pm 3,3$ versus $6,6 \pm 4,6 \mathrm{mg} / \mathrm{dL}$, resp.) $(P<0,05)$.

In logistic regression analysis female gender, not having vitamin D supplementation history, low serum albumin, and low BUN levels were significant independent predictors of vitamin $\mathrm{D}$ deficiency, while we were unable to demonstrate any relationship with vitamin $\mathrm{D}$ deficiency and presence of diabetes mellitus, serum creatinine, eGFR, being on hemodialysis, and being hospitalized (Table 4).

\section{Discussion}

Malatya City, which gets lots of sunlight, is at a latitude of 38:21 north, longitude 38:19 east, and an altitude of $998 \mathrm{~m}$ [17]. Average rainfall per year is $384,4 \mathrm{~mm}$. However, $62.1 \%$ of our patients had vitamin D deficiency, $23.6 \%$ vitamin $\mathrm{D}$ insufficiency, while $14.3 \%$ of the patients had adequate vitamin D stores. 
TABLE 4: Logistic regression models for probability of vitamin D deficiency.

\begin{tabular}{|c|c|c|c|c|}
\hline Variable & $\beta$ & S.E. & $P$ & Odds ratio (95.0\% C.I) \\
\hline Gender (1) & 0.907 & 0.277 & 0.001 & $0.404(0.2-0.6)$ \\
\hline Age & -0.007 & 0.009 & 0.404 & $0.993(0.9-1.0)$ \\
\hline Albumin & 0.892 & 0.253 & $<0.001$ & $2.5(1.5-4.0)$ \\
\hline Diabetes (1) & 0.319 & 0.352 & 0.365 & $1.376(0.7-2.7)$ \\
\hline Supplemented with vitamin D (1) & 1.188 & 0.329 & $<0.001$ & $0.305(1.6-0.6)$ \\
\hline eGFR & 0.005 & 0.005 & 0.309 & $1.005(0.9-1.0)$ \\
\hline Hospitalization & -0.231 & 0.322 & 0.475 & $1.259(0.6-2.3)$ \\
\hline Put on hemodialysis & 0.198 & 0.409 & 0.628 & $1.219(0.5-2.7)$ \\
\hline Constant & -4.488 & 1.137 & $<0.001$ & 0.011 \\
\hline
\end{tabular}

$n=280$. Forward stepwise (likelihood ratio) method; entry criteria $=P<0.05$.

$\beta$ : standard regression coefficient; 25(OH)D, 25-hydroxyvitamin D.

Vitamin D deficiency was reported to be high in the general medical inpatient population. The results of a study reported a $57 \%$ prevalence of vitamin $\mathrm{D}$ deficiency in 290 patients hospitalized in the general medical wards at Massachusetts General Hospital. Sixty-three percent of the patients studied in March and $49 \%$ of those studied in September had serum 25(OH)D concentrations of $15 \mathrm{ng} / \mathrm{mL}(37.4 \mathrm{nM} / \mathrm{L})$ or less. These authors reported that anticonvulsant-drug therapy, renal dialysis, nephrotic syndrome, and winter season were significantly associated with hypovitaminosis D [18].

Daoudi et al. [19] from Belgium reported that more than $60 \%$ of 332 patients hospitalized presented with serum concentrations below the lower limit of normal (12 $\mathrm{ng} / \mathrm{mL}, 29.9 \mathrm{nM} / \mathrm{L}$ ), whereas less than $5 \%$ reached $30 \mathrm{ng} / \mathrm{mL}$ (74.9 $\mathrm{nM} / \mathrm{L})$, a level generally recommended to avoid vitamin $\mathrm{D}$ insufficiency. These authors reported that young patients are not at a lesser risk of vitamin $\mathrm{D}$ deficiency than the older patients and women showed a lesser deficiency than men.

We found a higher prevalence of vitamin $\mathrm{D}$ deficiency in inpatients $(63.9 \%)$ than those of outpatients $(45.6 \%)$ in the nephrology department during early winter season $(P<0,05)$. However, in logistic regression analysis being female gender, not having vitamin D replacement previously, low serum albumin, and low BUN levels were significant independent predictors of vitamin $\mathrm{D}$ deficiency, while we were unable to demonstrate any relationship with vitamin $\mathrm{D}$ deficiency and presence of diabetes mellitus, serum creatinine, eGFR, and being hospitalized.

In our department we follow a vitamin $\mathrm{D}$ supplementation protocol which is similar to that recommended by K/DOQI guidelines [16] except cholecalciferol usage. If serum level of $25(\mathrm{OH}) \mathrm{D}<5 \mathrm{ng} / \mathrm{mL}(12.5 \mathrm{nM} / \mathrm{L})$, we prescribe $50000 \mathrm{IU}$ of vitamin D3 (cholecalciferol)/week orally/12 weeks and then monthly for six months. If serum level of $25(\mathrm{OH}) \mathrm{D}$ is between 5 and $15 \mathrm{ng} / \mathrm{mL}(12.5-37.4 \mathrm{nM} / \mathrm{L})$, we prescribe $50000 \mathrm{IU}$ of vitamin $\mathrm{D}_{3}$ (cholecalciferol)/weekly orally/4 weeks and then monthly for six months.

Of all patients, $55.7 \%$ were supplemented with vitamin D previously during followup in our nephrology unit. Vitamin D supplementation history was more common in outpatients.
Vitamin D deficiency was less common in patients supplemented with cholecalciferol previously; even vitamin D deficiency was also found among patients supplemented with cholecalciferol during followup. However, we do not have any information on compliance with vitamin D supplements.

In a retrospective study of 88 patients with CKD stages 1-5 and baseline 25-hydroxyvitamin D level $<30 \mathrm{ng} / \mathrm{mL}$ $(<75 \mathrm{nM} / \mathrm{L})$ performed by Qunibi et al. [20] treatment with ergocalciferol as recommended by K/DOQI guidelines managed to achieve in only $25 \%>$ or $=30 \mathrm{ng} / \mathrm{mL}(75 \mathrm{nmol} / \mathrm{L})$. These authors reported that current K/DOQI guidelines are inadequate for correcting vitamin $\mathrm{D}$ deficiency in $\mathrm{CKD}$ patients and recommended to monitor serum $25(\mathrm{OH}) \mathrm{D}$ levels regularly and to give appropriate vitamin D supplementation in order to achieve normal vitamin D status. It seems that our findings are consistent with those of Qunibi et al.

In our study during fall vitamin $\mathrm{D}$ deficiency was more common among women (69.3\% versus $43.5 \%)$; even percentage of the women supplemented with cholecalciferol previously was similar to that of men. In another a crosssectional study from Turkey Hatun et al. [21] demonstrated that vitamin D insufficiency (43.8\%) and deficiency $(21 \%)$ are common among Turkish adolescent girls at the end of the winter (in April). This finding is more striking in girls who wear concealing clothing, and they did not improve significantly during the summer, whereas the vitamin D status of girls in the other groups did.

In Turkey, the main source of vitamin $\mathrm{D}$ is cutaneous synthesis because there is no food fortification with vitamin $\mathrm{D}$, and supplementation of vitamin $\mathrm{D}$ is not a routine practice. Veiling or staying indoors is common in our female patients, although we did not have any information about these in this study. It is possible that these women benefited less from the decreased sunlight through the fall months than men do, possibly by exposing their skin less to the sun.

Our study has several limitations. Firstly, this study suffers from all the limitations of retrospective observational studies that rely on existent databases, and the information was collected only at one point in time. Secondly, we have no information about compliance with vitamin D supplements. However, we had some information about common practice and results. 
As a conclusion, vitamin $\mathrm{D}$ deficiency seems to be an important problem in both inpatients and outpatients of nephrology in Turkey. Women are at more risk of deficiency and may therefore need to consume higher doses of the vitamin D. Monitoring serum 25(OH)D levels regularly and replacement of vitamin D are important. A governmental mandate about the supplementation of foods with vitamin D is urgently needed in Turkey.

\section{References}

[1] M. F. Holick, "Vitamin D: a millenium perspective," Journal of Cellular Biochemistry, vol. 88, no. 2, pp. 296-307, 2003.

[2] M. F. Holick, "Vitamin D: the underappreciated D-lightful hormone that is important for skeletal and cellular health," Current Opinion in Endocrinology and Diabetes, vol. 9, no. 1, pp. 87-98, 2002.

[3] E. L. Smith, N. C. Walworth, and M. F. Holick, "Effect of $1 \alpha, 25-$ dihydroxyvitamin $\mathrm{D}_{3}$ on the morphologic and biochemical differentiation of cultured human epidermal keratinocytes grown in serum-free conditions," Journal of Investigative Dermatology, vol. 86, no. 6, pp. 709-714, 1986.

[4] S. Nesby-O’Dell, K. S. Scanlon, M. E. Cogswell et al., "Hypovitaminosis D prevalence and determinants among African American and white women of reproductive age: Third National Health and Nutrition Examination Survey, 1988-1994," American Journal of Clinical Nutrition, vol. 76, no. 1, pp. 187-192, 2002.

[5] H. Taskapan, O. Baysal, D. Karahan, B. Durmus, Z. Altay, and O. Ulutas, "Vitamin D and muscle strength, functional ability and balance in peritoneal dialysis patients with vitamin D deficiency," Clinical Nephrology, vol. 76, no. 2, pp. 110-116, 2011.

[6] C. Pipili, C. Dimitriadis, N. Sekercioglu, J. M. Bargman, and D. D. Oreopoulos, "Effect of nutritional vitamin D preparations on parathyroid hormone in patients with chronic kidney disease," International Urology and Nephrology, vol. 44, no. 1, pp. 167-171, 2012.

[7] A. Lishmanov, S. Dorairajan, Y. Pak, K. Chaudhary, and A. Chockalingam, "Elevated serum parathyroid hormone is a cardiovascular risk factor in moderate chronic kidney disease," International Urology and Nephrology, vol. 44, no. 2, pp. 541-547, 2012.

[8] V. Tangpricha, E. N. Pearce, T. C. Chen, and M. F. Holick, "Vitamin D insufficiency among free-living healthy young adults," American Journal of Medicine, vol. 112, no. 8, pp. 659662, 2002.

[9] E. A. González, A. Sachdeva, D. A. Oliver, and K. J. Martin, "Vitamin D insufficiency and deficiency in chronic kidney disease: a single center observational study," American Journal of Nephrology, vol. 24, no. 5, pp. 503-510, 2004.

[10] H. Taskapan, F. F. Ersoy, P. Passadakis et al., "Severe vitamin $\mathrm{D}$ deficiency in chronic renal failure patients on peritoneal dialysis," Clinical Nephrology, vol. 66, no. 4, pp. 247-255, 2006.

[11] H. Taskapan, M. Wei, and D. G. Oreopoulos, “25(OH) vitamin $\mathrm{D}_{3}$ in patients with chronic kidney disease and those on dialysis: rediscovering its importance," International Urology and Nephrology, vol. 38, no. 2, pp. 323-329, 2006.

[12] M. E. Bindal and H. Taskapan, "Hypovitaminosis D and insulin resistance in peritoneal dialysis patients," International Urology and Nephrology, vol. 43, no. 2, pp. 527-534, 2011.
[13] H. Taskapan, F. F. Ersoy, P. Passadakis et al., "Body pain during daily activities in patients on peritoneal dialysis," Dialysis and Transplantation, vol. 34, no. 2, pp. 58-115, 2005.

[14] M. L. Melamed, B. Astor, E. D. Michos, T. H. Hostetter, N. R. Powe, and P. Muntner, "25-Hydroxyvitamin D levels, race, and the progression of kidney disease," Journal of the American Society of Nephrology, vol. 20, no. 12, pp. 2631-2639, 2009.

[15] A. S. Levey, J. P. Bosch, J. B. Lewis, T. Greene, N. Rogers, and D. Roth, "A more accurate method to estimate glomerular filtration rate from serum creatinine: a new prediction equation. Modification of diet in renal disease study group," Annals of Internal Medicine, vol. 130, pp. 461-470, 1999.

[16] National Kidney Foundation, "K-DOQI clinical practise guidelines for bone metabolism and disese," American Journal of Kidney Diseases, vol. 42, supplement 3, pp. 1-201, 2003.

[17] Y. Unal, T. Kindap, and M. Karaca, "Redefining the climate zones of Turkey using cluster analysis," International Journal of Climatology, vol. 23, no. 9, pp. 1045-1055, 2003.

[18] M. K. Thomas, D. M. Lloyd-Jones, R. I. Thadhani et al., "Hypovitaminosis D in medical inpatients," The New England Journal of Medicine, vol. 338, no. 12, pp. 777-783, 1998.

[19] N. Daoudi, R. Karmali, and M. Fuss, "Evaluation of vitamin D deficiency in hospitalized patients in Brussels," Revue Medicale de Bruxelles, vol. 30, no. 1, pp. 5-10, 2009.

[20] W. Y. Qunibi, A. Abdellatif, S. Sankar et al., "Treatment of vitamin $\mathrm{D}$ deficiency in $\mathrm{CKD}$ patients with ergocalciferol: are current K/DOQI treatment guidelines adequate?" Clinical Nephrology, vol. 73, no. 4, pp. 276-285, 2010.

[21] S. Hatun, O. Islam, F. Cizmecioglu et al., "Subclinical vitamin D deficiency is increased in adolescent girls who wear concealing clothing," Journal of Nutrition, vol. 135, no. 2, pp. 218-222, 2005. 


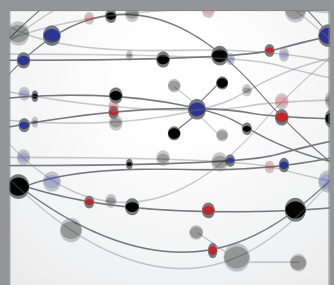

The Scientific World Journal
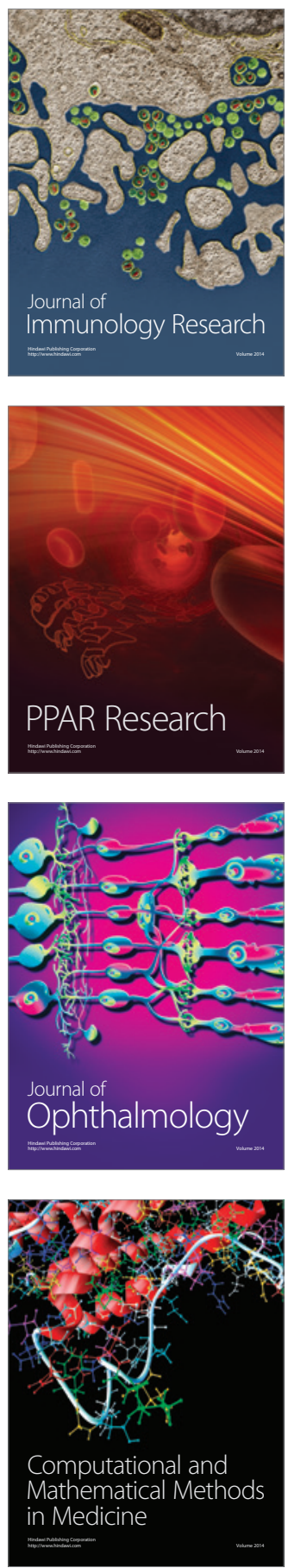

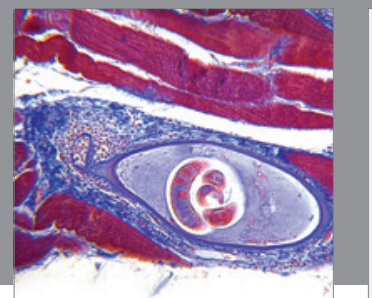

Gastroenterology

Research and Practice
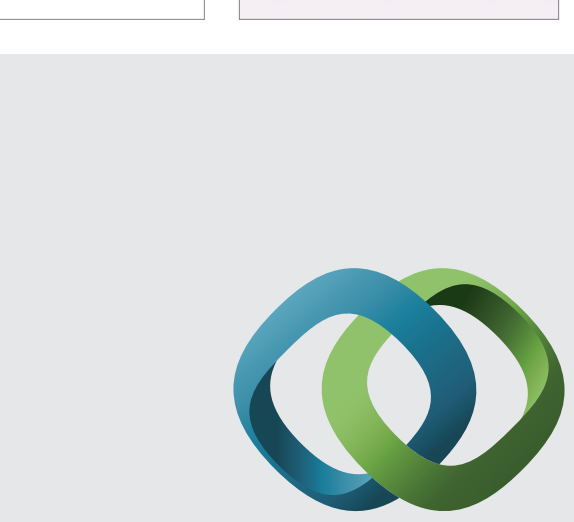

\section{Hindawi}

Submit your manuscripts at

http://www.hindawi.com
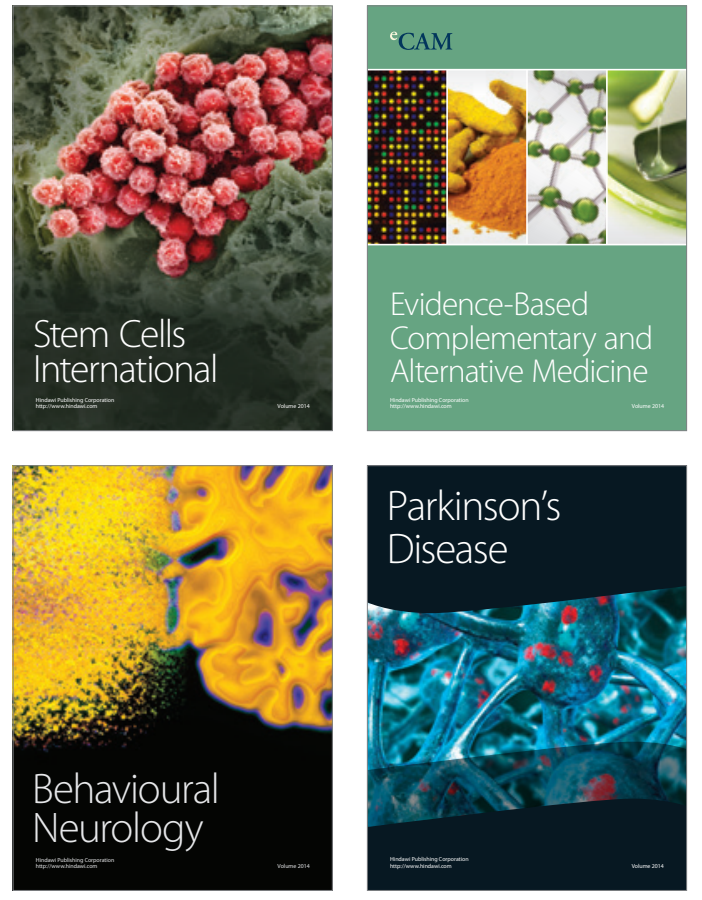
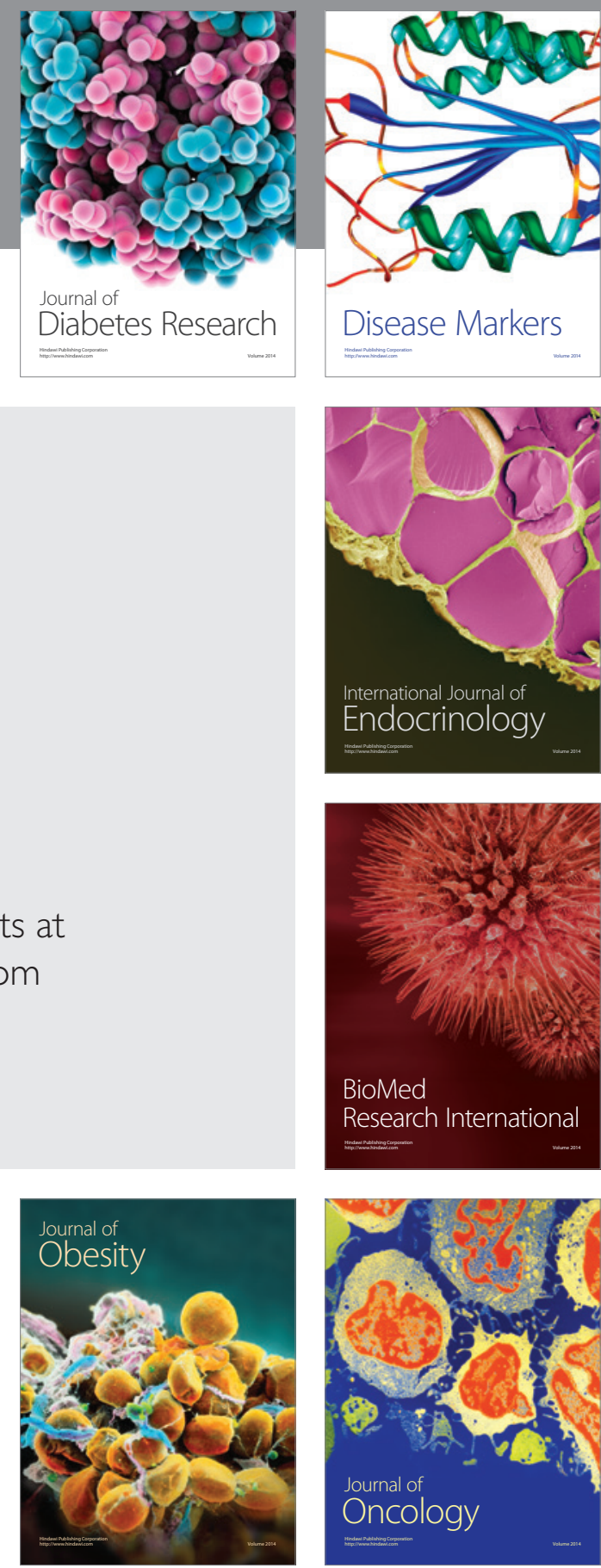

Disease Markers
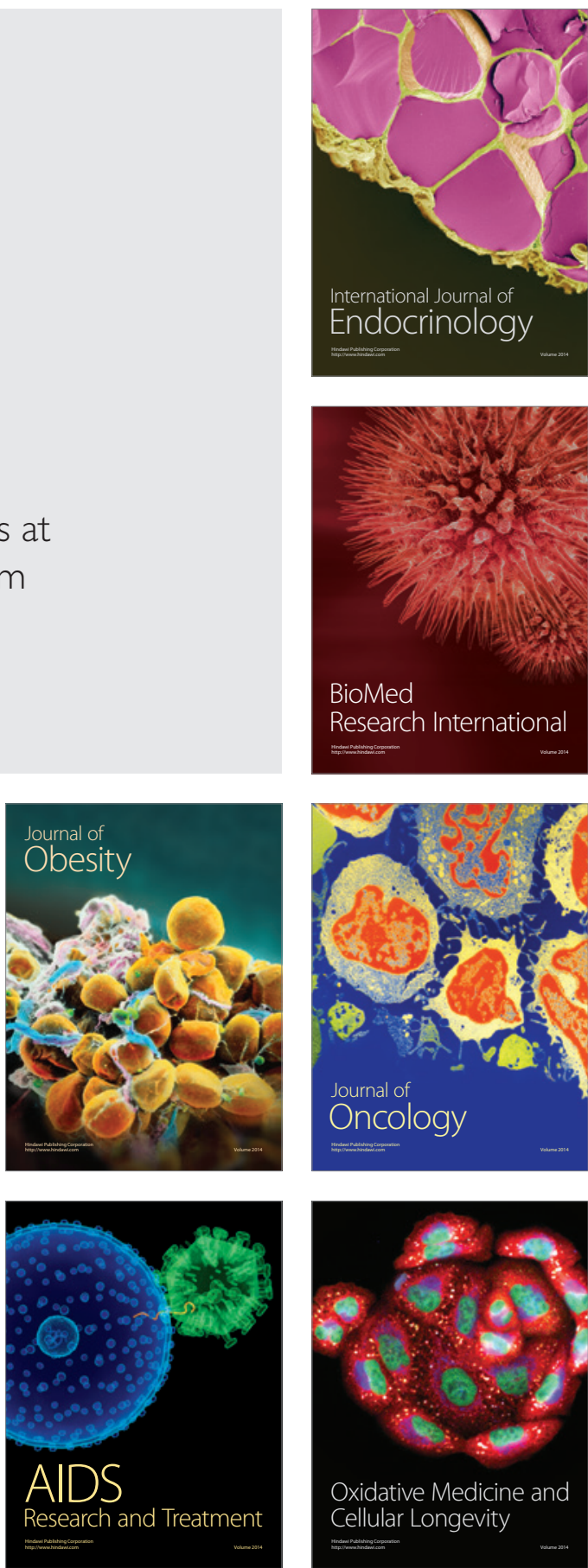